\title{
Difficult Tracheotomy in Advanced Anaplastic Thyroid Carcinoma
}

\author{
İleri Anaplastik Tiroid Karsinomunda Zor Trakeotomi
}

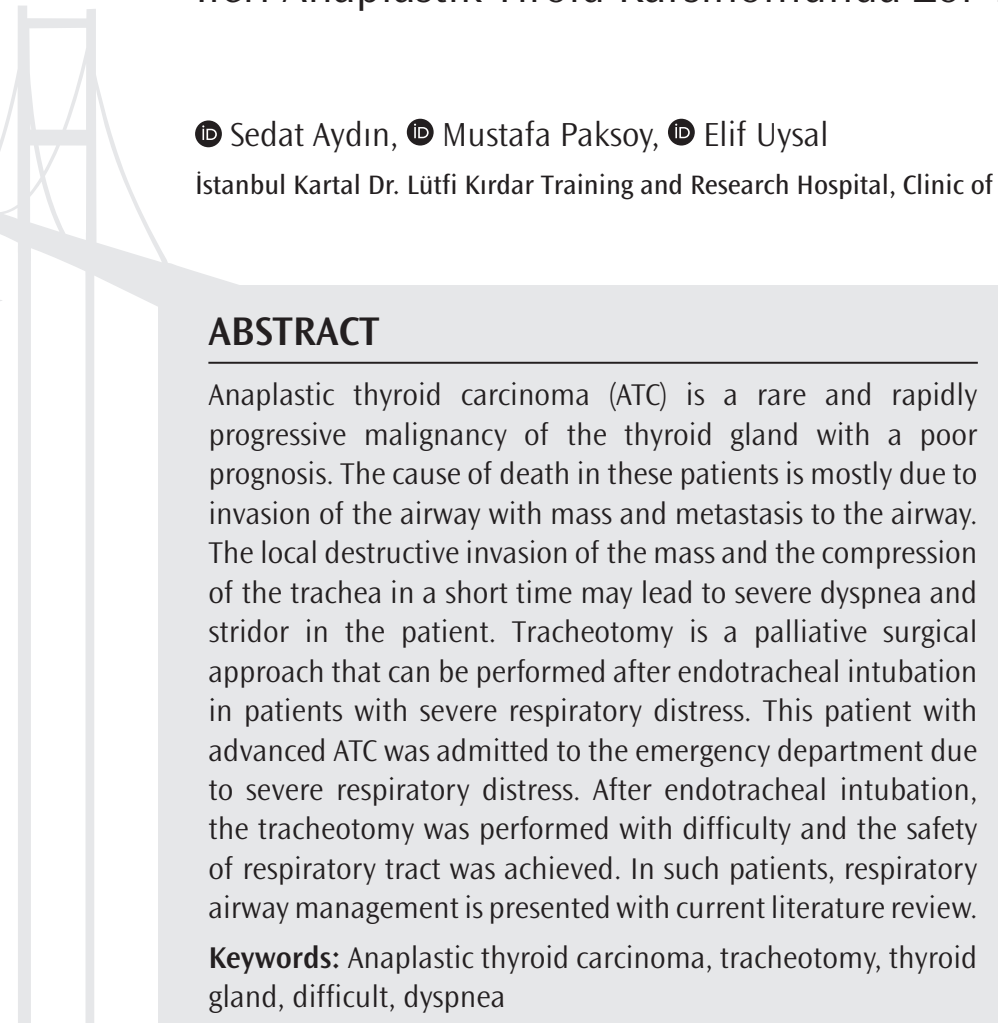

öz

Anaplastik tiroid karsinomu (ATK) tiroid bezinin nadir görülen kötü prognozlu, hızlı ilerleyen bir malignitesidir. Bu hastalarda ölüm sebebi çoğunlukla hava yolunun kitle ile invazyonu ve metastaz sebebiyle olur. Kitlenin lokal destrüktif invazyonu ile kısa sürede trakeada oluşturduğu bası hastada şiddetli dispne ve stridora yol açabilir. Trakeotomi ileri derecede solunum sıkıntısı olan hastalarda endotrakeal entübasyon sonrasında uygulanabilecek palyatif bir cerrahi yaklașımdır. İlerlemiș ATK olan bu olgumuz ileri derecede solunum sıkıntısı sebebiyle acil servise başvurdu. Endotrakeal entübasyon sonrasında güçlükle uygulanan trakeotomi ile solunum yolu güvenli hale gelmiştir. Bu tür hastalarda solunum yolu yönetimi güncel literatür gözden geçirilerek sunulmuştur.

Anahtar Kelimeler: Anaplastik tiroid karsinomu, trakeotomi, tiroid bezi, zor, dispne

\section{Introduction}

Anaplastic thyroid carcinoma (ATC) constitutes 2-5\% of all thyroid malignancies and has a very poor prognosis. It usually emerges in the $6^{\text {th }}$ and $7^{\text {th }}$ decades of life with a rapidly growing mass in the neck. As a result of the invasion of this mass to the local tissues, mostly hoarseness, stridor and dyspnea are observed. Airway problems occur due to tracheal invasion or external pressure in the early stages of the disease $(1,2)$. American Thyroid Society (ATA) guide recommends surgical resection in areas where the tumor can be resected and that chemoradiotherapy be given as initial therapy in patients with extensive tumor spread, followed by completion surgery if possible $(3,4)$. Survival rates are $20 \%$ at one year after diagnosis and $5 \%$ at five years, and the mean life expectancy after diagnosis is 6-15 months. In most of these patients, the cause of death is metastasis and airway problems (5-8).
Airway control is difficult in a tumor with such poor prognosis. Airway problems may be the complaints of patients or may develop during the treatment process. Physicians often have difficulty in deciding when to open tracheotomy or perform surgical decompression. Prior to the publication of the ATA treatment guideline, the literature was limited in providing airway control in ATC (3). This guideline recommends opening tracheotomy under general anesthesia under appropriate conditions in patients with severe respiratory distress in ATC only. In this article, we aimed to present a tracheotomy approach to a patient with ATC who presented with respiratory distress.

\section{Case Report}

A 49-year-old male patient was diagnosed with ATC after a biopsy in the health center he had applied to because of developed pain and swelling on his neck 6 months ago. He presented to the emergency department 
of our hospital because of the increasing swelling in his neck and severe respiratory distress and stridor presenting in a short time. In the examination of the patient who had no pathology in his medical history and family history, it was observed that he had difficult respiration and inspiratory stridor in the inspection. The mass was covering the whole neck and anatomic triangulation points could not be differentiated. It was stiff, fixed, about $15 \times 20 \mathrm{~cm}$ and mostly lateralized to the right side of the neck. The flexible nasopharyngoscopy revealed bilateral cord vocal paralysis and increased secretion in the piriform sinuses. The opening between the two vocal folds was $2-3 \mathrm{~mm}$. Previous neck and thorax computed tomography of the patient were reported as "15x17 cm mass lesion, involving both thyroid lobes and isthmus, having irregular margins and exhibiting heterogeneous enhancement, and margins cannot be clearly distinguished from the surrounding muscles and soft tissues, and sternocleidomastoid muscles" (Figures 1 and 2). Informed consent was obtained from the patient. The mass pushed the trachea to the right and was compressing the airway from the anterolateral side. An urgent tracheotomy was planned for breathing difficulty. However, because important triangulation points in the neck were lost,

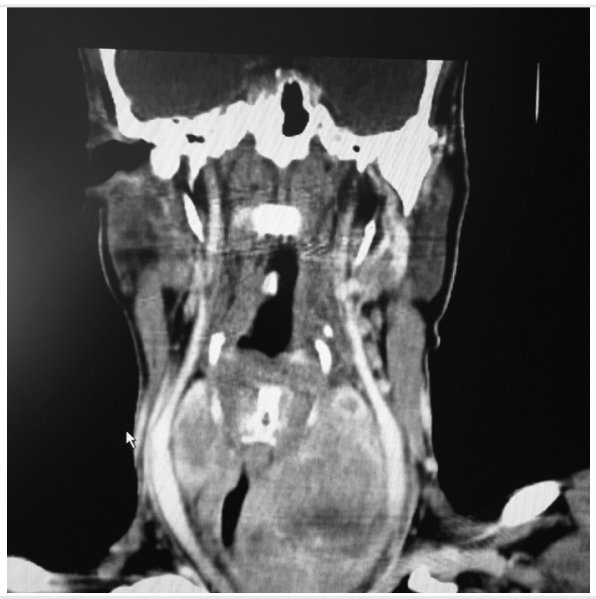

Figure 1. In coronal view of computed tomography scan of head and neck; a mass of $15 \times 17 \mathrm{~cm}$ with irregular margins and heterogeneous contrast enhancement is observed, which invades both thyroid lobe and isthmus, and thus cannot be clearly distinguished from surrounding soft tissues

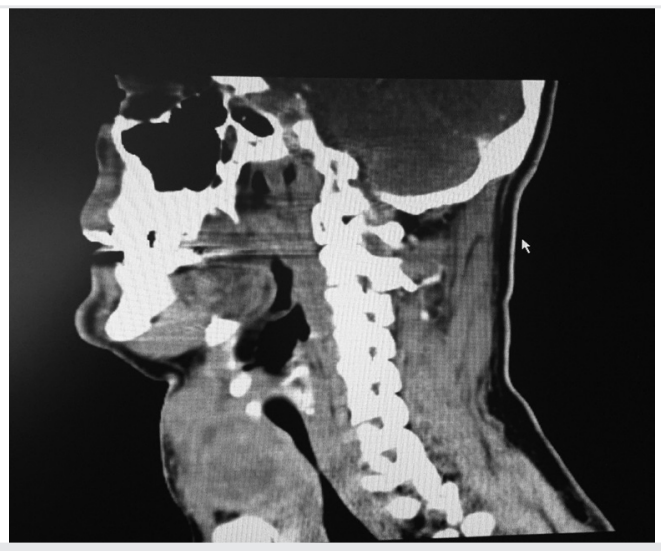

Figure 2. In sagittal view of computed tomography scan of head and neck; it is observed that the same mass has filled the thyroid space and narrowed the tracheal lumen it was thought that tracheotomy would be safer after endotracheal intubation and endotracheal intubation was performed under general anesthesia. Then, a conventional Kocher incision was planned in case apron flap incision was required. During the subcutaneous flap elevation, which was difficult due to bleeding, stiff and hemorrhagic thyroid mass adherent to strap muscles and other surrounding tissues were encountered. The incision was extended to the apron flap incision as previously thought, in order to control the mass. It was seen that the mass deviated the trachea to the right, extending to the posterior end of the sternum. Thyroid cartilage of the larynx was detected as an anatomical triangulation point in the neck. It was aimed to reach tracheal rings by following this structure downwards. In the meantime, with the help of the "harmonic scalpel ${ }^{\circledR}$ " vascular sealing device that provided technological innovation, the thyroid right lobe and the mass thought to be derived from this lobe were partially excised and the tracheal cartilages were reached. The trachea was entered from the place where the second ring was thought to be (Figure 3). The patient was sedated and was taken to the intensive care unit with intravenous antibiotic and fluid support. Because the patient had postoperative induration and discharge in his neck, antibiotic treatment was continued as ultrasound revealed suspected abscess. The patient died in the intensive care unit after 14 days due to sudden bradycardia and cardiac arrest.

\section{Discussion}

Treatment options of ATK include surgery, chemotherapy, radiotherapy and combined therapies. However, the assessment of patients' airway is of critical importance. The cause of death in patients with ATC is often distant metastases with airway involvement, bilateral vocal cord paralysis and respiratory problems. The tracheotomy or cricothyrotomy procedure provides palliative and transient airway solution. This issue should be discussed with the patient and his/her relatives and consent must be taken. The survival in patients who underwent tracheotomy was

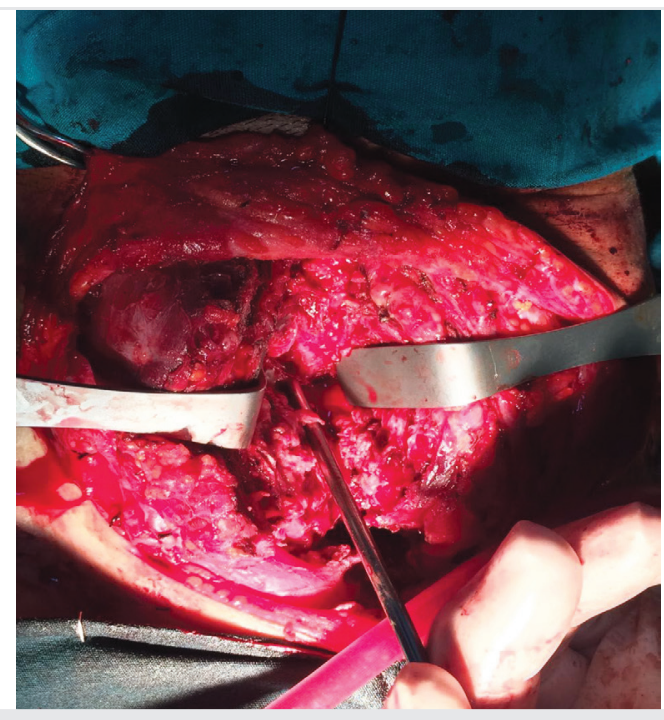

Figure 3. A view of tracheotomy after partially tumor excision of the istmus region, severe destructive mass in the trachea drastically eliminated the anatomical guiding points 
found to be shorter than in patients who underwent "debulking" surgery (9). However, it is important to note that in patients with ATC, respiratory problems are likely to occur until the tracheotomy stage. Because of the presence of malignancy and radiotherapy in these patients, wound healing in the tracheotomy region is not fast and healthy. For this reason, the tumor tissue can continue to grow from the tracheotomy line or its surroundings, leading to bleeding (10). In our case, abscess formation was detected after tracheotomy.

The fact that the mass causes respiratory distress in patients with ATC means that the mass grows and closes the surgical access ways to the trachea in the midline of the neck. Another problem is the displacement of the trachea due to the compression effect of the mass during tracheotomy. ATA recommends that tracheotomy should be performed under operating conditions and under general anesthesia as we did in our case (3-11).

As the ATC is progressing rapidly, a large mass is often encountered in the neck midline when respiratory distress occurs in patients. Because of this mass, "debulking" surgery is required to reach the trachea. Displacement of the trachea, stiffness and blood supply of the mass should be considered during this surgery. At this stage, the importance of preoperative radiological evaluation of the patient is revealed. The shortest and easiest way of access to the tr achea should be evaluated preoperatively and the size of the surgery should be determined preoperatively. During "debulking" surgery, electrocautery should be used to reduce both the duration of surgery and post-operative bleeding. Standard tracheotomy cannulae can be short in these patients because reaching the trachea with "debulking" surgery also increases the distance between the skin and the trachea. In this stage, lengthadjustable cannulas or intubation tube can be used (9). It is important to fix the cannula or tube to prevent dislocation (12). In our case, since length-adjustable tracheotomy cannula was not available at the time, a 7.0 endotracheal intubation tube was used and it was fixed to the surrounding neck skin.

In addition, the light to be advanced through the trachea can be followed by fiberoptic endoscopy during tracheotomy to help locate the trachea, which is displaced by external pressure (9). In our case, trachea was revealed after "debulking" surgery and there was no need for fiberoptic endoscopy guidance.

In conclusion, after the laryngeal examination with flexible nasopharyngoscopy and tracheotomy is planned for maintaining airway safety in cases of ATC admitting to emergency departments with severe respiratory distress, one first should get ready for a problematic tracheotomy following endotracheal intubation in the operating room conditions, as in our case. We believe that tracheotomy would be safe by reaching tracheal cartilages guided by thyroid notch and thyroid cartilage with a large incision, in difficult tracheotomy cases where triangulation points disappear, as in our case.

Informed Consent: Informed consent was obtained from the patient.

Peer-review: Externally peer-reviewed.

Author Contributions: Concept - S.A.; Design - S.A.; Supervision - S.A., M.P., E.U.; Resources - S.A., E.U.; Materials - S.A., M.P., E.U.; Data Collection and/or Processing - S.A., M.P., E.U.; Analysis and/or Interpretation - S.A., E.U.; Literature Search - S.A., M.P.; Writing Manuscript - S.A., E.U.; Critical Review - S.A.

Conflict of Interest: No conflict of interest was declared by the authors.

Financial Disclosure: The authors declared that this study received no financial support.

\section{References}

1. Ain KB. Anaplastic thyroid carcinoma: a therapeutic challenge. Semin Surg Oncol 1999; 16: 64-9.

2. Wein RO, Weber RS. Anaplastic thyroid carcinoma: palliation or treatment? Curr Opin Otolaryngol Head Neck Surg 2011;19:113-8.

3. Smallridge RC, Ain KB, Asa SL, Bible KC, Brierley JD, Burman KD, et al. American thyroid association guidelines for management of patients with anaplastic thyroid cancer. Thyroid 2012; 22: 1104-39.

4. Ișık A, Fırat D, Yılmaz I, Peker K, Idız O, Yılmaz B, et al. A survey of current approaches to thyroid nodules and thyroid operations. Int J Surg 2018; 54 100-4.

5. Veness MJ, Porter GS, Morgan GJ. Anaplastic thyroid carcinoma: dismal outcome despite current treatment approach. ANZ J Surg 2004; 74: 559-62.

6. Rodriguez JM, Pinero A, Ortiz S, Moreno A, Sola J, Soria T, et al. Clinical and histological differences in anaplastic thyroid carcinoma. Eur J Surg 2000; 166 : 34-8.

7. Are C, Shaha AR. Anaplastic thyroid carcinoma: biology, pathogenesis, prognostic factors, and treatment approaches. Ann Surg Oncol 2006; 13: 45364.

8. Lang BH, Lo CY. Surgical options in undifferentiated thyroid carcinoma. World J Surg 2007; 31: 969-77.

9. Mani N, McNamara K, Lowe N, Loughran S, Yap BK. Management of the compromised airway and role of tracheotomy in anaplastic thyroid carcinoma. Head Neck 2016; 38: 85-8.

10. Ranganath R, Shah MA, Shah AR. Anaplastic thyroid cancer. Curr Opin Endocrinol Diabetes Obes 2015; 22: 387-91.

11. Haddad RI, Lydiatt WM, Ball DW, Busaidy NL, Byrd D, Callender G, et al. Anaplastic thyroid carcinoma, Version 2.2015, J Natl Compr Canc Netw 2015; 13: $1140-50$

12. Shaha AR, Ferlito A, Owen RP, Silver CE, Rodrigo JP, Haigentz M Jr, et al. Airway issues in anaplastic thyroid carcinoma. Eur Arch Otorhinolaryngol 2013; 270: 2579-83. 